\title{
How Community Institutions Create Economic Advantage: Jewish Diamond Merchants in New York
}

\author{
Barak D. Richman
}

\begin{abstract}
This article argues that Jewish merchants have historically dominated the diamond industry because of their ability to reliably implement diamond credit sales. Success in the industry requires enforcing executory agreements that are beyond the reach of public courts, and Jewish diamond merchants enforce such contracts with a reputation mechanism supported by a distinctive set of industry, family, and community institutions. An industry arbitration system publicizes promises that are not kept. Intergenerational legacies induce merchants to deal honestly through their very last transaction, so that their children may inherit valuable livelihoods. And ultraOrthodox Jews, for whom participation in their communities is paramount, provide important value-added services to the industry without posing the threat of theft and flight.
\end{abstract}

Barak D. Richman is Assistant Professor of Law, Duke University School of Law. The author would like to express his deep thanks to the many friends, colleagues, and mentors who have offered extremely helpful guidance to this project. Specific thanks go to Laura Beny, Lisa Bernstein, Michael Broyde, Robert Cooter, Rui de Figueredo, Einer Elhauge, Oliver Hart, Christine Jolls, Louis Kaplow, Michael Levine, Eva Meyersson Milgrom, Paul Milgrom, Arti Rai, Steven Shavell, Andrei Shleifer, Pablo Spiller, Oliver Williamson, and three anonymous reviewers. He also appreciates comments provided by Bridget Butkevich and the panel on the Economic Consequences of Religious Identity at the 2004 Conference on Religion, Economics and Culture, and the Contracts workshop at the 2005 American Law and Economics Association annual meetings, where presentations of this article received valuable feedback. Additional thanks go to the participants at the Law, Economics, and Organization Workshop at Harvard Law School and the Wednesday Lunch Student Seminar at Harvard Law School for both valuable comments and timely encouragement. Michael Hannon provided superior research assistance. Finally, the author is deeply grateful for sustained funding from the Duke University School of Law and the John M. Olin Center for Law, Economics, and Business at Harvard Law School. 


\section{INTRODUCTION}

Why are America's diamond merchants primarily Jewish? Jewish predominance in the diamond trade spans several centuries and continents, and activity in the modern-day industry is most concentrated in Jewish communities populated by the ultra-Orthodox. This article argues that community institutions within the Jewish community support diamond transactions and generate efficiencies that other economic organizations cannot achieve. Consequently, these community institutions give Jewish merchants comparative advantages over rivals.

The distinguishing feature of the diamond industry lies in the typical diamond transaction: trade in diamonds invites extraordinarily lucrative opportunities for industry players to cheat, most notably to steal another's diamonds. Credit sales, which are highly preferable to simultaneous exchange due to liquidity constraints and seasonal demand, routinely put scores of diamonds into the hands of individual diamond merchants who have not paid for them. Although the law makes certain security mechanisms available to those who extend such credit, such as attaching a lien to the diamonds or assigning collateral to secure the extension of credit, diamond merchants have systematically rejected use of public courts and state-created law to enforce contracts and police behavior. Instead, they rely on a private system that is less costly, more reliable, and thus superior to state-based alternatives. Diamond merchants reliably fulfill contractual obligations without the threat of state intervention, and this reliability in turn enables these merchants to credibly commit to fulfilling executory obligations. This ability to enforce executory contracts that public courts cannot enforce, and thus that potential industry rivals cannot enforce, propels the Jewish community's success. ${ }^{1}$

1. The important feature of executory contracts for this analysis is its arrangement of time-inconsistent exchange. Such exchange occurs when parties A and B contract to exchange items of value, but time elapses between the moment party $\mathrm{A}$ gives a good to $\mathrm{B}$ and the moment B gives a good or a payment to A, i.e., there is a separation between the "quid" and the "quo." A paradigmatic example is the credit sale, in which the buyer receives the goods and pays the seller at a later date. It has been argued, by none less than Judge Richard Posner, that "the most important thing which [contract] law does is to facilitate exchanges that are not simultaneous by preventing either party from taking advantage of the vulnerabilities to which sequential performance may give rise." Wisconsin Knife Works v. National Metal Crafters, 781 F.2d 1280, 1285 (7th Cir. 1986). Although it was not until the 1960s that modern economists finally came to appreciate the critical role that reliable contract enforcement plays in economic development, both Adam Smith ([1776] 1976) and Montesquieu ([1748] 1977) placed emphasis on legal structure as prerequisites to successful economies. Smith put it best: "Commerce and manufacturers can seldom flourish long in any state which does not enjoy a regular administration of justice, in which the people do not feel themselves secure in the possession of their property, in which the faith of contracts is not supported by law, and in which the authority of the state is not supposed to be regularly employed in enforcing the payment of debts from all those who are able to pay" (910). 
Section II begins with a fuller articulation of the historical puzzle presented by Jewish predominance in the diamond industry, and Section III describes with particularity the structure of the diamond trade, paying special attention to the unique difficulties, or contracting hazards, of typical diamond transactions. Section IV, which addresses this article's central question, then examines how diamond traders enforce executory agreements. ${ }^{2}$ It analyzes the economic players in the diamond industry, many of whom are Orthodox Jews, and explains how they are induced to cooperate with fellow diamond merchants and, despite profound attractions to cheat, comply with their contractual obligations. Section V briefly reviews how some similarly structured trading networks, including but not limited to those that dominate other diamond centers, manage contract enforcement to overcome the ineffectiveness of state-sponsored courts. Section VI offers concluding remarks and some reflections on the future of the Jewish diamond merchant community.

\section{AN HISTORICAL PUZZLE}

Jewish merchants have long played an important role in the world's diamond industry. In the eleventh century, two Jewish brothers, living in Cairo as prominent bankers and diamond merchants, supplied the Fatimid Caliph Empire with precious stones. Throughout the Middle Ages, when India was the world's leading source of raw diamonds, Jewish communities along the Indian Ocean trade routes-Egypt, Maghreb, and the shores of Southern Europewere home to diamond traders and cutters. Beginning in 1492, Sephardic Jews escaping the Inquisition in Spain and Portugal built the world's then-largest diamond market in Holland and enjoyed a virtual monopoly for several centuries. In seventeenth and eighteenth century Germany, a sizable Jewish community in Hamburg monopolized the diamond trade to the courts of Europe. And when eighteenth century England's trade with India made London a lucrative diamond trade center, a majority of the East India Company's diamond importers were Jewish (Grayzel 1968, 426-27; Baron et al. 1975, 158-61; Shainberg 1982, 301-11). These high-level connections in the diamond world culminated with the Jewish family-controlled De Beers syndicate, which in the 1960s managed the production and marketing of close to 100 percent of the world's uncut diamonds and today controls approximately 65 percent. $^{3}$

2. An additional, and critical, question in this analysis examines why (not just how) the diamond industry employs community institutions, rather than alternative enforcement mechanisms such as vertical integration, to enforce agreements. This issue is discussed separately in an accompanying article (Richman 2004), which explains how private enforcement protects transactions that are beyond the reach of public courts while avoiding the bureaucratic costs of vertical integration.

3. De Beers's control of the supply of rough diamonds has declined in recent years as some mines have begun selling directly to diamond merchants. See note 16 below. 
This predominance has lasted into the twenty-first century, for Jewish merchants remain disproportionately represented in the world's diamond centers of Antwerp, Tel Aviv, and New York. Interestingly, the modern-day Jewish presence in these diamond centers reaches deeply and most categorically into the supporting occupations of diamond cutting and diamond brokering. Eighty percent of all of Amsterdam's 30,000 cutters in the early twentieth century were Jewish, and in Antwerp, one-third of all cutters and threefourths of all brokers were Jewish. Similar percentages have been maintained in today's diamond centers of New York, Antwerp, and, more obviously, Israel (Shainberg 1982). In New York's diamond industry, which is the focus of this article, the Jewish presence is most profound at the ground level, as the industry's brokers and cutters are disproportionately comprised of ultraOrthodox Jews, adherents to an insular and highly ritualistic version of Jewish practice. ${ }^{4}$ A visit to Manhattan's 47th Street and the New York Diamond Dealers Club (DDC), home to the industry's trade association and the locus of the city's diamond trade, immediately reveals the Orthodox Jewish influence in the New York diamond world. The street's many shops and the DDC's trading hall are filled with merchants wearing long, untrimmed beards, speaking Yiddish, and dressed in black suits, overcoats, and black hats or caftans. ${ }^{5}$

Jewish predominance in the industry is somewhat of a puzzle, and it invites numerous (and not necessarily mutually exclusive) explanations. One possible explanation invokes history. In pre-Enlightenment Europe, Jews were prohibited from owning land, ousted from merchant guilds, and excluded from traditional brands of handicrafts; they thus were forced into becoming suppliers of finished goods and extenders of credit. ${ }^{6}$ Jewish communities also suffered a history of expulsions and forced emigrations from Christian rulers, so they were drawn to professions with easily portable inventories (Arkin 1975). ${ }^{7}$ Jews were similarly marginalized in many Middle-Eastern and North African countries, so Jewish merchants in those areas also searched for professions that required small fixed investments (Roth 1938; Arkin 1975; Brenner and Kiefer 1981; Ayal and Chiswick 1983). The diamond trade met these conditions and thus became attractive to early Jewish merchants. However, while these observations explain why Jewish merchants were drawn to the diamond industry and why Jews distanced themselves from occupations

4. For a thorough discussion of ultra-Orthodox Jewry, including a description of its origins and modern-day expression, see Heilman (1992) and Silber (1992).

5. The New York Times called the DDC and New York's diamond district "an anachronism, a 17th-century industry smack in the middle of a 21st century city" Weber (2001).

6. Several prominent Jewish historians, including Roth $(1938,228 ; 1961 \mathrm{a})$ and Abrahams (1896), argue that Jewish occupational selection was a product of the many of state restrictions on Jewish economic activity.

7. It is a popular view that, for similar reasons, Jews invested in portable human capital, rather than physical capital (e.g., Brenner and Kiefer 1981), but Botticini and Eckstein (2005) instead attribute Jewish success in urban occupations to the community's widespread literacy, which resulted from an emphasis on religious text-based education. 
that involved nonportable fixed assets, they do not explain Jewish success over non-Jewish competitors. Early predominance suggests not just that the diamond industry was a last resort, but that Jewish merchants enjoyed a comparative advantage.

A related explanation relies on path dependence, suggesting that today's prevalence of Jewish diamond merchants is merely a product of historical momentum. ${ }^{8}$ This approach argues that Jewish merchants seized industry leadership during a seminal period, perhaps through some fortuitous advantage or historical accident, and that past leadership positioned them favorably compared to subsequent challengers. This explanation has genuine appeal for several reasons. First, discussed above, numerous factors centuries ago induced Jewish merchants to pursue trades with portable goods, and second, discussed below, the trade exhibits entry barriers that severely restrict outsiders from challenging industry leadership. However, as Section V illustrates, entry is not entirely foreclosed. Entrants into the diamond industry, like Jewish merchants, exhibit the ability to privately enforce executory contracts in large part because they live in communities structurally similar to their Jewish counterparts. ${ }^{9}$ This suggests that entry into the diamond industry is, like any other industry, limited to those who meet the demands of the trade, and those who lead the diamond industry enjoy leadership because they meet those demands best.

Another explanation could rest on a theory of human capital (Becker 1993). This theory suggests that Jewish families or institutions developed know-how that enables Jewish merchants to excel in the diamond trade. However, if the unifying commonality among Jewish merchants is their religious ethnicity, then a human capital theory would argue that an element of Jewish education or socialization develops skills that contribute to succeeding in the diamond industry. To be sure, certain elements of Jewish education and socialization help Jewish merchants organize the diamond supply chain, such as the prevalence of Yiddish in certain sects, widespread preferences for religious goods, and the interconnectedness of large families in intimate communities. ${ }^{10}$ In addition, the insularity of certain sects and

8. Path dependency is a popular theory in political science literature, popularized in the seminal article by Alexander Gerschenkron (1962). A good modern example is Zysman (1994).

9. As is discussed in Section V, there is a small but growing non-Jewish component of the DDC's 1,800 members. Approximately 15 percent (up from just 2 percent in the late 1980s) of current DDC members are Indian and have connections to India's prosperous trade. The Indian community's role in the diamond industry is discussed below, but it is worth noting here that the Indian merchants come disproportionately from a single insular sect, the Palanpuri Jain, who claim strong ethnic ties and have a tradition of family-based businesses. The mechanisms that enforce agreements between Jewish merchants may have parallel mechanisms in the Indian community.

10. See notes 39, 52-61 and accompanying text below. Botticini and Eckstein (2005) advance this sort of human capital theory in arguing that Jewish religious learning promoted literacy, which in turn led to Jewish economic success in medieval merchant industries. But this theory cannot explain Jewish diamond industry leadership in the twentieth century, where literacy is commonplace. 
the intimacy of family networks might facilitate the transmission of critical skills that only experts can impart, such as diamond cutting and the ability to inspect and appraise gemstones. ${ }^{11}$ However, recognizing that Jewish practice and beliefs play instrumental roles in economic life is distinct from a human capital theory that identifies specific skills and training that lead to economic success. Jewish practice might (as is argued here) contribute to Jewish merchants' ability to police transactions, credibly commit to comply with credit obligations, and manage the industry's assorted demands, but there is no obvious link between Jewish practice and the requisite skills to excel in the diamond trade.

A fourth possible explanation for Jewish predominance relies on a theory suggesting that members of a group might act cooperatively to maximize the group's collective income, even if it requires individuals to make sacrifices to their own income (Krueger 1963). In this "ethnic cartel" model, merchants in an insular community pledge to charge competitive prices only to its own community members and to sell goods only at oligopoly prices to nonmembers. As a result, outsiders are at a disadvantage in entering a supply chain and competing against insiders. This theory also probably has some merit. The industry's entry barriers have secured a lucrative source of income for Jewish communities for many generations, and the insularity of those communities, combined with the industry's strong preference for secrecy and distrust of outsiders, likely gave favorable treatment to insiders and had anticompetitive effects similar to many cartels. However, one problem with the ethnic cartel model, particularly as it is applied to the centuries-old diamond industry, is that it presumes a cartel has the ability to outlast market forces. Modern antitrust scholars are generally skeptical of most cartels' ability to police their own members and prolong supercompetitive prices, especially in markets (like the market for diamonds) that exhibit highly differentiable goods and unpredictable demand (Posner 1969). In contrast, the diamond industry's seemingly anachronistic distribution system has sustained itself for over 500 years. Moreover, history illustrates that the diamond industry has, in fact, opened its doors to entrants from other ethnic groups even as Jewish predominance has remained, with cross-ethnic trade being a common feature. ${ }^{12}$ Consequently, ethnic predominance is explained not by cartel behavior, but rather by a comparative advantage that participating community members

11. Some concentrated centers of diamond cutting expertise have developed much like other cottage industries of skilled labor or specialized technology. Porter (1985, chap. 9) describes generally how geographic proximity sustains interrelationships among business units that generate competitive enterprises. Diamond cutting centers include Idar-Oberstein, a provincial town in the picturesque Hunsrück Mountains in Germany's Rhineland that "turns out stonecutters the way Frankfurt does bankers," and Nor-Hajen, Armenia, a long-time source of master cutters (Clerizo 2004; Rubin 2001).

12. See note 9 above; see also Section V below. 
enjoy. The proper inquiry, then, is what do successful entrants have in common with those who have long dominated the industry?

This article follows an approach that rests on an efficiency analysis. While forces invoked by the above alternative theories-historical accidents combined with institutional inertia and entry barriers, family networks that support the acquisition of specific skills and human capital, and anticompetitive collusion facilitated by ethnic familiarity - all likely play some role in explaining Jewish predominance, it argues that today's Jewish merchants owe their success in the diamond trade to a comparative advantage that enables them to organize diamond transactions more efficiently than potential rivals. ${ }^{13}$ The primary comparative advantage Jewish merchants enjoy is the ability to credibly commit to pay for the diamonds they purchase on credit. Jewish merchants owe this advantage to complementarities between the demands for governing diamond transactions and the traditional structure of Jewish communities. In short, Jewish community institutions can enforce executory contracts that are beyond the reach of public courts and thus beyond noncommunity members as well. ${ }^{14}$

The next section describes the unusual challenges that diamond credit sales present and explains why public courts cannot enforce executory contracts. Section IV then explains in detail how Jewish community institutions serve as unusually effective enforcement mechanisms and thus create a comparative advantage for Jewish merchants. Since the traditional social structure that pervaded Jewish communities throughout the world before the Enlightenment

13. The diamond industry is already the beneficiary of several valuable economic examinations, but previous scholarship placed its emphasis elsewhere. The early works focused on De Beers's restrictive sales policy, which bundles many heterogeneous diamonds together and charges the approximate average price. Yoram Barzel $(1977,1982)$ first explained that this unusual practice prevented buyers from engaging in costly efforts to examine and appraise individual diamonds before their making a purchase, thus permitting De Beers to recoup some of those savings by charging a higher price. Barzel (1977, 304-05) concluded, "[h]ad the contents of a particular bag been available for appraisal by all buyers, each probably would have spent resources to determine the properties of the diamonds. ... The incentive for De Beers to engage in this peculiar form of trade seems to be that buyers are now in a position to spend on the actual purchase of the diamonds the amount they otherwise might have spent on collecting information." Kenney and Klein (1983) articulated a similar argument in their famous paper examining of "block booking." The most thorough and most notable economic examination of the diamond industry was Lisa Bernstein's (1993) seminal article, which describes the diamond industry's elaborate system of private arbitration and its significant efficiencies compared to public courts. In this and other work (Bernstein 1996, 2001), Bernstein's identification of certain procedural efficiencies typical of private adjudication is a lasting contribution to commercial law.

14. For these reasons, this article closely follows the influential work of Janet Landa (1981, 1988, 1994; Carr and Landa 1983), whose Ethnically Homogeneous Middleman Group (EHMG) theory observes that ethnic trading networks in the developing world can organize exchange at uniquely low transaction costs. It is notable that this article, unlike Landa's work, examines the role of community enforcement in a contractual setting where the public courts are readily available, which suggests that the diamond industry reveals an instance of court failure. 
remains intact in New York's ultra-Orthodox communities, an understanding of what generates current Jewish comparative advantage might also explain the community's past economic success.

\section{DIAMOND TRANSACTIONS}

\section{A. A Diamond's Path and Time-Inconsistent Exchange}

In the $\$ 60$ billion diamond jewelry industry, a diamond's path from the mine to the consumer goes through several intermediaries. ${ }^{15}$ The journey for most stones begins in African, Australian, and Canadian mines. Approximately 65 percent of these rough (i.e., unpolished) diamonds go to the De Beers-controlled Central Selling Organization (CSO) in London, ${ }^{16}$ and the CSO distributes its supply of rough diamonds through four brokers, who sell presorted boxes of diamonds to 125 specific merchants, known as "sightholders," during individual "sights," or viewing sessions, in London. ${ }^{17}$ These bundles are sold at a nonnegotiable price, and if the sightholder refuses to purchase at the set price, the holder will not be invited to future sightings. ${ }^{18}$ Accordingly, sightholders rarely refuse CSO terms since they reap substantial rents from their valuable position atop the distribution chain.

Sightholders then sell these rough diamonds to a network of individual dealers, and approximately 80 percent of these initial sales occur in Antwerp's four diamond bourses. Then the process of cutting and sorting begins, in which Antwerp merchants either arrange for polishing the stones themselves or sell rough diamonds to other dealers who arrange for cutting in India, China, Israel, New York, and other locations. Dealers continue to resell the rough and polished

15. Global retail sales of diamond jewelry have been estimated at $\$ 58.7$ billion for 2003 . In 2002 , when global retail sales were $\$ 56.9$ billion, the sale of rough diamonds from mines was $\$ 8.35$ billion and the value of diamond content in global retail jewelry sales totaled $\$ 14.5$ billion. Thus, the total mark-up from rough diamonds to polished wholesale prices is about 75 percent.

16. The De Beers cartel owns the mines of approximately 50 percent of the world's diamonds, with the additional 15 percent entering its control through exclusive purchase agreements. As recently as the 1990s, De Beers controlled 80 percent of the world's diamonds and controlled 100 percent in the 1960s. The recent decline in market share resulted from mines in Russia, Australia, and Canada electing to market their diamonds directly in Antwerp instead of participating in the CSO cartel. These developments, plus advances in laser technologies for cutting and polishing diamonds (see Section $\mathrm{V}$ below), have prompted De Beers to change its business strategy away from market control and toward marketing a brand name (Weber 2001; Muller 2001).

17. De Beers has reduced the number of sightholders over the past few years. Kenny and Klein (1983) spoke of approximately 300 sightholders and Bernstein (1992) wrote about 150-200 sightholders. Recent reports now list 125 sightholders, and some indications suggest that De Beers plans to further reduce that number to as little as 60 . This is part of De Beers' recent effort to consolidate the industry (see Muller 2001).

18. For a discussion of the efficiency implications of this distribution method, see Kenny and Klein (1983). 
diamonds, in increasingly smaller bundles, until they reach a jewelry manufacturer for commercial sale. Many dealers also use brokers, who work on small commissions, to assist these sales and find the best price for a given stone.

The reliance on the numerous intermediaries is necessitated by widely divergent valuations for individual stones. Different end consumers place very different values on a given stone (depending both on an intended use for a diamond and on subjective judgments), so finding the optimal buyer for a specific stone is a highly profitable enterprise. However, determining a diamond's qualities and ultimate value is extremely difficult to do without conducting a personal inspection, and the process of sorting and evaluating diamonds is time-consuming and effort-intensive (Barzel 1977, 1982; Kenny and Klein 1983). Consequently, the industry is home to many middlemen who create value and earn substantial profits by ascertaining the particular demands of individual end-users, learning how much buyers will pay, evaluating the qualities of individual stones, and then matching certain types of stones with particular buyers. The matching process through intermediaries continues even after stones reach New York. In one day, a diamond can move from one end of New York's 47th Street diamond center to the other, doubling in value after passing through seven or eight hands (Weber 2001). Accordingly, a typical diamond will pass through many transactions before it reaches a consumer, and such sales regularly involve passionate negotiations over price, payment schedule, method of payment, and credit security.

Despite the steady stream of diamond transactions, neither the flow of diamond supply nor the flow of demand is constant. On the supply end, there are ten CSO sights each year, one held approximately every five weeks. The sightholders are required to pay the CSO in full within seven days of the sight, but it can take as long as four months for a manufacturer to sort, polish, and sell all of the diamonds in the bundle. Similarly, dealers who are not sightholders purchase their supply of diamonds on a cycle that shadows schedule of sights. On the demand side, retail demand for diamonds is highly seasonal, as 30-40 percent of all U.S. sales occur in November and December. By contrast, the pace of manufacturing, particularly diamond cutting and polishing, which involves one cutter and one stone at a time, is constant. ${ }^{19}$ Therefore, efficient utilization of diamond cutters requires polishing stones throughout the year, despite the irregularity of supply and demand. ${ }^{20}$

19. In fact, cutting technology for large stones has changed very little over the past centuries. Cutters hold a diamond firmly in a metal grip and deliberately place it at a desired angle against a rotating grinding wheel. In earlier generations, the grinding wheel was rotated mechanically by hand cranks or foot petals, whereas modern grinding wheels are electric and use more sophisticated grips, but the underlying process is essentially the same.

20. Historically, diamond merchants have always had to balance capacity constraints in manufacturing and polishing with waves of supply and demand. For example, an economic boom in 1820 Amsterdam led to the emergence of many new factories, but work was never constant and cutters were hired only temporarily. 
Consequently, selling diamonds on credit is far more preferable than simultaneous exchange. Credit sales allow merchants to adjust their inventories and manufacturing schedules to the ebbs and flows of supply and demand. Moreover, liquidity constraints are very tight for merchants since most merchants are self-employed or work for small family businesses, not for heavily capitalized corporations, and many dealers are simply unable to pay upfront for substantial purchases (dealers generally concede that they can get a significantly better price for a stone if they extend credit to their buyers). Accordingly, most dealers match payments for credit purchases with the anticipated revenue from downstream sales, and the predominant diamond transaction is the executory contract that features a time-inconsistent exchange and a separation of the quid from the quo. ${ }^{21}$ The role of credit in diamond transactions is so central that the market for diamonds has been called "an implicit capital market" (Bernstein 1992).

\section{B. The Challenge-Enforcing Diamond Executory Contracts}

Given the importance of credit sales, the diamond industry depends overwhelmingly on the reliable enforcement of executory contracts. However, while most industries can employ state-sponsored courts to enforce payment after the delivery of goods, ${ }^{22}$ public courts are toothless to enforce credit sales for diamonds. Diamonds are easily portable and command extreme value throughout the world. A diamond thief encounters little difficulty in hiding unpaid-for or stolen diamonds from law enforcement officials, fleeing American jurisdiction, and selling the valuable diamonds to black market buyers. ${ }^{23}$ The courts' failure to prevent flight amounts to a failure to enforce the executory contract.

21. An alternative to selling diamonds on credit is for a diamond merchant to seek credit elsewhere. However, as Bernstein (1992) explains, diamond merchants can obtain credit from each other at a lower cost than they could elsewhere. First, they save the additional set of transaction costs that accompany a third party, such as a bank or other provider of credit. Second, if diamond merchants transact with each other regularly, they have more information about the buyer's creditworthiness than would a bank, thus reducing adverse selection costs.

22. Of course, it has been long recognized, particularly since Stewart Macaulay's (1963) seminal work, that businesspeople in all industries largely resolve their disputes without resorting to state courts. Similar modern-day instances of informal contract enforcement appear in Ellickson (1989; 1993), McMillan and Woodruff (1999), Fafchamps (1996), Banerjee and Duflo (2000), and Clay (1997).

23. Diamond theft continues to be a severe problem for the industry despite technological advances in security. In 2003, rough diamonds worth approximately $\$ 100,000,000$ were stolen from Antwerp vaults, and in 2004 petty thieves stole more than $\$ 300,000$ worth of Elvis Presley's jewelry from the Elvis-A-Rama museum, including the King's ruby diamond ring and his diamond pendant and chain. Relatedly, fugitives continue to transfer their assets into diamonds before escaping law enforcement. A recent example is Martin Frankel, the troubled fugitive financier whose collapsed financial schemes prompted federal prosecution. During his attempted escape from U.S. authorities, he arranged a shadowy purchase of several million dollars of diamonds hours before his flight from the United States (Pollack 2002). 
The failure of public courts requires diamond merchants to rely on trust-based exchange. ${ }^{24}$ Mutual trust among merchants-which the New York Times has called "the real treasure of 47th street"-assures dealers that by maintaining a trustworthy reputation, they will remain in good community standing and preserve the opportunity to engage in future lucrative transactions (Starr 1984). Through this mutual trust, dealers comfortably engage in executory contracts despite the unreliability of state courts.

However, trust is an "elusive notion" (Gambetta 1988) and has been invoked to explain a wide variety of phenomena. Prior scholarship has formulated trust as a societal bond that organizes national industry (Dore 1983; 1989, chap. 9), a familial or community bond that organizes ethnic trading networks (Carr and Landa 1983; Landa 1994), and, in a more intimate context, a necessity for personal functioning. Scholars have also used trust to explain broad trends of economic development, from the success of credit associations (Geertz 1962; Ardener 1964; Velez-Ibanez 1983) to regional and national economic performance (Putnam 1993; Fukuyama 1995). In recent years, many prominent thinkers have developed simplified conceptions of trust that amount to purely self-interested behavior. James Coleman (1990), for example, translates "relations of trust" that are popular in the sociology literature into a rational choice formulation, and Russell Hardin (2002) advances an "encapsulated interest" theory that states that individuals trust those persons whom they believe will act to advance their well-being. Similar accounts by game theorists explain mutual trust with utility-maximizing models that rest on rational and calculative actors (Dasgupta 1988; Kreps 1990). The approach taken in this article resembles the calculative trust that is captured by game theorists, but it more closely follows Oliver Williamson's "hyphenated trust" that, while adhering to the economist's taste for utility maximization, recognizes that since "man, after all, is a 'social animal,' then socialization and social approvals and sanctions are also pertinent" (Williamson 1993, 475). ${ }^{25}$

However, utility-maximizing notions of "trust" invite other challenges. Partha Dasgupta has observed, "[i]f the incentives are 'right,' even a trustworthy person can be relied upon to be untrustworthy" (Dasgupta 1988, 54), and such are the "incentives" presented by diamond transactions. According to simple game theory, parties to a transaction will not trust their counterpart unless both parties know that the present value of profits from future exchange will exceed the one-time gain from cheating - this, of course, is a simple

24. The undesirability of alternative institutions to secure diamond transactions, such as vertical integration, is discussed in Richman (2004).

25. Hyphenated trust might resemble the pursuit of self-interest within an embedded social framework (see Granovetter 1985), and this combination of calculativeness and embeddedness might best capture the mutual trust shared between diamond merchants. Trust in these circumstances is deliberate and purposeful, but it occurs within a rich network of family and community institutions that shape interactions and preempt calculativeness. 
version of the iterated Prisoner's Dilemma (Axelrod 1984). However, the Prisoner's Dilemma for the diamond transaction presents a particularly difficult hurdle for cooperation because while cooperating often yields only nominal profits, cheating, such as running off with unpaid diamonds, produces a tremendous monetary gain. Many credit sales involve large quantities of diamonds, and brokers regularly have many diamonds in their possession that they do not own, so the opportunity to steal another's diamonds is both readily available and tremendously valuable. ${ }^{26}$ In contrast, the industry's competitiveness makes profit margins very thin-especially for brokers, whose commissions can be as low as 1 to 2 percent of a sale. ${ }^{27}$ Moreover, multilateral cooperation throughout a market is significantly more difficult to explain than bilateral cooperation between two players, since players in a multilateral game do not know with whom they will transact in the future and may not know the past actions of their current business partners.

Despite these features of the diamond transaction - the extremely valuable opportunities to cheat, the relatively low payoffs from dealing honestly, the unavailability of public courts, and the need to know that one's business partners are trustworthy-the diamond industry is able to sustain widespread multilateral cooperation. Part of this is undoubtedly because merchants do more than maximize intertemporal profits. General notions of reciprocal fairness and cooperation motivate diamond merchants, just as experimental results have shown they motivate most individuals. ${ }^{28}$ Also, as a general matter, diamond merchants value their standing and participation in their communities and do not want to lead a fugitive's life. ${ }^{29}$ Nonetheless, because of the extreme value of cheating and the corresponding costliness to a merchant who has been cheated, general notions of fairness and morality are insufficient to secure trust-based exchange, and the industry relies instead on several distinctive industry and community institutions. The most important source of the industry's success lies in the particular identities and preferences of the individuals involved in diamond transactions.

26. Cheating in the paradigmatic sense is refusing to pay for diamonds received from another merchant, but cheating opportunities are by no means limited to theft. Other ways that merchants can cheat-and issues that cause serious concern among diamond merchants - include submitting payment late and lying about a diamond's quality or origin.

27. Profit margins tend to vary according to a merchant's location on the distribution chain. Merchants who are perched atop the distribution chain, in particular De Beers sightholders, likely benefit from some oligopoly rents and do enjoy lucrative businesses. The paradigmatic challenge remains, however, particularly as an end-game problem.

28. For surveys of empirical evidence suggesting that many individuals, even in economic settings, are strongly motivated by concerns for fairness and reciprocity, see Fehr and Falk (2001). There are also efforts to formalize notions of fairness in generally applicable models. Compare Fehr and Schmidt (1999) with Rabin (1993).

29. This issue is discussed extensively in Section IV. See notes 53-58 below. 


\section{ENFORCING EXECUTORY CONTRACTS}

Sustaining reputation-based exchange relies on mechanisms that inform all parties of the reputations, or past behavior, of potential business partners. This section first describes how the New York Diamond Dealers' Club, the diamond district's bourse and the industry's epicenter, serves the critical role of disseminating reputation information and enabling trust-based exchange between individuals who do not intimately know each other. Still, even under full information, the lucrative opportunities to cheat suggest that cooperation would be extremely difficult to sustain, so the remainder of this section describes how intergenerational family businesses and tightly knit ethnic communities enable cooperation.

\section{A. The New York Diamond Dealers Club ${ }^{30}$}

Sustained cooperation in New York's diamond industry supports a tremendous amount of commerce. Nearly half of the world's $\$ 60$ billion diamond jewelry sales are in the United States (Feifer 2004; Time 2004), and 47th Street merchants handle over 95 percent of the diamonds imported into the United States (Lueck 1997). Manhattan's crowded diamond district and the DDC serve as the gateway to the lucrative American market.

In addition to providing a high-security trading hall that is safe for diamond inspection and sales, the DDC also serves as the industry's trade association and provides structure to diamond transactions. Comprised of 1,800 members, the DDC issues trading rules to govern diamond sales and provides a mandatory private arbitration system to resolve all disputes between merchants. This private system replaces any opportunity to seek redress from a state court, and any member that does attempt to adjudicate in state courts will be fined or suspended from the club (DDC Bylaws, Art. XXII, § 1a). DDC members are elected to serve as arbitrators, and only members held in the highest esteem win election. The arbitration panels deliberate in secret, pass down rulings without written justifications or creating case law, and all arbitration rulings are final. The private

30. The New York Diamond Dealers Club was founded in 1931 with twelve founding incorporators and fifty original members. Modeled after the diamond bourses that served Europe's older and larger diamond industries, its membership grew substantially in 1944-45 when many European dealers were able to immigrate to the United States (Lubin 1982). Many European diamond dealers fleeing Europe before the Nazi invasions of Holland and Belgium sought temporary refuge in Cuba, Mexico, and Brazil before returning to Europe or immigrating to the United States (Federman 1985). 
arbitration system has been hailed as an efficient and highly effective enforcement mechanism. ${ }^{31}$

However, like state courts, the DDC's private arbitration system is wholly incapable of enforcing agreements on its own and is toothless in punishing diamond theft. The DDC's arbitration board can issue fines or revoke an individual's Club membership, but these sanctions are effective only if the party intends to continue transacting in diamonds and are meaningless if that party decides never to transact again. While decisions by the DDC's arbitration committee are enforceable in New York's state courts, ${ }^{32}$ such appeals very rarely occur since state courts also cannot prevent a thief from escaping to a hidden location and disposing of stolen diamonds. In any event, many dealers, particularly middleman brokers, are essentially judgment proof, so remedies from both public courts and private arbitration panels will be unable to recover adequate damages from a person who has squandered another's diamonds and subsequently becomes unable to pay. ${ }^{33}$ Illustrating the limitations of both public and private enforcement mechanisms is the following admission by one diamond dealer: "the truth is that if someone owes you money, there's no real way to get it from him if he doesn't want to pay you." 34

Consequently, the reach of the DDC arbitration board is limited to cooperating parties, as it has no inherent power to force any individual to pay an arbitration award. Merchants comply with the DDC arbitration board

31. Because DDC arbitrators are highly familiar with the diamond industry and archetypal diamond transactions, their expertise yields certain sizable administrative savings (for example, their expertise substantially aids the evidentiary process of recognizing stolen goods). Plus, DDC arbitration procedures are tailored for typical disputes, so litigation costs are relatively low and arbitration rulings are swift, reflect the accuracy of experts, and assess appropriate remedies. For a full discussion of the administrative efficiencies of the DDC's private arbitration system, see Bernstein (1992, 135-38, 148-51).

32. A party can appeal an arbitration board decision to New York state court only if there is a procedural irregularity. The board's substantive decisions are not reviewed. See Rabinowitz v. Olewski, 473 N.Y.S.2d 232 (N.Y. App. Div. 1984); Goldfinger v Lisker, 68 N.Y.2d 225 (N.Y. 1986).

33. Concerns about payment are contractual hazards that place a risk on the seller. A second category of contractual hazards involves risks assumed by the buyer. For example, diamonds can receive laser treatments that improve the stone's color, but a treated diamond is less valuable than an untreated diamond of equal color. Since only a complex laser examination can detect whether a diamond is treated, a buyer often makes a purchase based on a seller's representation.

Similarly, a diamond's origins cannot be verified upon inspection. This has become increasingly relevant with the rise of "conflict diamonds" mined in some African nations (particularly Angola, Sierra Leone, and Congo) by political-military organizations determined to overthrow a recognized government. Since the conflict diamond sales fund some of the most brutal military campaigns, many consumers refuse to purchase them and many jewelers refuse to use them (note: none of the diamonds sold by the Central Selling Organization are conflict diamonds). They nonetheless make their way through an elaborate global network from the African mines to Antwerp for sale. De Beers estimates that conflict diamonds constitute 4 percent of the world's market, though the U.S. and U.K. governments suspect that the figure is significantly higher (Buchan et al. 2000; Smith 1999; Oppenheimer 1999).

34. Interview with the author, March 2001. 
only to preserve good reputations and protect the opportunity to engage in future diamond transactions. Accordingly, the DDC's role is purely informational, and the power of its dispute resolution system rests on the degree to which it supports trust-based exchange and can foreclose future transactions to uncooperative merchants. The DDC fulfills this role by facilitating information exchange and publicizing individual reputations. ${ }^{35}$

The DDC supports information exchange with several mechanisms. First, the floor of the trading hall is bustling with information about parties and market conditions, and some traders spend time on the trading floor just to keep abreast of available information. Traders on the floor will ask others about potential business partners and get references, and supplementary credit reports about diamond buyers float throughout the trading community. ${ }^{36}$ Thus, the Club creates both a physical and a relational infrastructure that facilitates information sharing between members.

A second mechanism is the wall of the trading floor. The wall posts the pictures, background, and references of any visitor to the Club, providing easy referral for potential business dealings (most visitors are required to be sponsored by a member, who is cited as a reference along with the visitor's picture). The wall also announces the nomination of potential new members and invites current members to comment on the candidate's reputation. Most importantly, the wall publicizes the judgments from recent disputes before the arbitration board and posts the picture-not unlike a "Wanted" posterof any party who is responsible for an outstanding debt. This information is shared with all of the world's bourses, so pictures of delinquent debtors from across the world are broadcast prominently in the DDC trading hall. Conversely, maintaining good standing as a DDC member-and preventing one's picture from ever reaching the wall-also functions as an important information signal.

The DDC's system of arbitration and information exchange thus sets the stage for other family-and community-based institutions to enforce the industry's executory contracts; if the DDC announces the verdict, then these complementary institutions are the sheriffs that enforce it. The DDC is able to rely on community institutions because individuals who share intimate

35. Milgrom, North, and Weingast (1990) similarly characterize the role of private judges in supporting trade between sixteenth century Law Merchants in the Champagne Fairs. The judges' power did not arise from an inherent power to enforce agreements but rather from the ability to disseminate information and support a reputation mechanism.

Historically, the foremost function of all diamond bourses and their less established predecessors has always been to facilitate a flow of information about market participants and business opportunities (Shainberg 1982, 308). Bernstein $(1992,121)$ puts it succinctly: "The bourse is an information exchange as much as it is a commodities exchange."

36. One useful information source on creditworthiness is the Rapaport Diamond Report, which collects information about many diamond purchasers, particularly jewelry manufacturers, and assigns each a credit rating. It is the Moody's of the diamond industry. 
family and community ties dominate its membership. ${ }^{37}$ As was noted above, nearly 85-90 percent of DDC members are Jewish, and a visitor is struck by a pervasive presence of Ultra-Orthodox Jewry in the Club. ${ }^{38}$ Since Orthodox Jews tend to live in discrete, insular communities, familiar business relationships are also familiar community relationships, and the members' ties to each other do not end at the Club's door. Moreover, family ties also connect Club members, as many members gain entry through the sponsorship of close relatives. ${ }^{39}$ In short, extended family and community networks cement the Club's larger community and reinforce the intimate familiarity and interdependence that Club members have with each other.

\section{B. The Parties}

The driving force behind diamond merchants' ability to participate in trust-based exchange is their membership to unique sociodemographic groups. This is a system that bases the credibility of one's commitments on his identity, ${ }^{40}$ and a merchant's membership in these intimate groups is what enables him to make contractual promises that fellow merchants find reliable. This ability to make trustworthy promises-to commit credibly to a contractual obligation that state courts cannot enforce-is what gives New York's diamond merchants comparative advantages over outsiders. ${ }^{41}$ They can purchase goods on credit and gain valuable market information from an insular network.

The identity of each diamond merchant can be placed in one of two distinct categories. In one category fall the "long-term players." These merchants enjoy family connections to the industry and usually have a proprietary stake in a family-run business. They gain entry into the industry through

37. The DDC currently has approximately 1,800 members, and in most years there is a waiting list for membership. Dealers petitioning for membership must survive a rigorous informational review: applicants must (1) have worked in the industry for at least two years, (2) comply with the board of directors' requests for information, and (3) have his picture posted on the trading floor wall for ten days so members have an opportunity to comment (DDC Bylaws, Art. 3, § 8). More lenient precedures, however, govern the admission of the immediate family members of DDC members in good standing (DDC Bylaws, Art.3, § 3b).

38. The other significant contingent of the DDC's membership is Indian, who comprise approximately 10 percent of all members, see note 9 above, and are discussed at length in Section $\mathrm{V}$ below.

39. Another gateway to entry-one that invites community members and excludes othersis the predominance of Yiddish and Hebrew among merchants. Many ultra-Orthodox use Yiddish as the vernacular, and the many Israelis in the industry make Hebrew widely used.

40. Given the nature of the diamond industry, this article's use of male pronouns is generally accurate and is not intended to be an excluding shorthand. But female diamond merchants have been playing increasingly significant roles (see Pogrebin 1998).

41. While diamonds pose significant credibility challenges for credit sales, Brinig (1990) argues that they served to solve a credibility problem of another sort, that "engagement rings were part of an extralegal contract guarantee" that bound parties to their promise to marry and replaced the old cause of action for a breach of a marriage promise. 
the sponsorship of a family elder, and they employ younger family members to whom they eventually bequeath the family business. Thus, the long-term players are inducted into intergenerational family businesses, work in the family business for their entire careers, and then pass on the same business to their descendents. The second group consists of religious community members, and most workers in this category belong to ultra-Orthodox Jewish communities. These workers are committed to the austere lifestyles of ultraOrthodoxy, yet they frequently are in possession of enormously valuable caches of diamonds. The pervasiveness of this second group, the industry's "diamond-studded paupers," is a truly striking feature of the diamond trade. ${ }^{42}$ When they fill the DDC trading halls, they transact as their ancestors did in Europe's bazaar markets, though instead of trinkets or small crafts, these paupers peddle caches of precious diamonds.

Interestingly, a merchant's identity tends to predict his role in the distribution network: long-term players are primarily dealers or buyers (including jewelry manufacturers), and religious paupers serve chiefly as contractors. ${ }^{43}$ Contracted parties include brokers, who search for a buyer and retain a small sales commission, and diamond cutters, who cut or polish a diamond for a fixed fee. Both brokers and cutters assume possession of the diamond but never own it, and they give neither payment nor collateral to the diamond owner when they take possession.

Stark differences separate the two categories of merchants-the longterm players from the religious paupers, the dealers from the contractors. Most but not all the long-term players are Jewish, whereas the paupers are ultraOrthodox Jews. And unlike the long-term players, the contractors find their way into the industry through community connections. These contractors generally are not connected to family businesses and do not build up a business that they hope to bequeath to a child. In fact, these ultra-Orthodox prefer that their sons commit their lives to Torah study and find financial support without having to work regularly. Whereas the long-term players desire to build up profitable businesses that they can bequeath to their descendants, the contractors hope to accumulate sufficient resources for themselves only so they can leave the business and devote their time to religious study. ${ }^{44}$

42. Daily buses carry scores of workers directly from Boro Park, Monsey, and Williamsburgall homes to concentrated ultra-Orthodox Jewish communities- to the diamond district on 47 th Street.

43. These categories are not perfect, as there is some overlap. Some brokers maintain an inventory of diamonds and sell for capital gains rather than commissions, and some dealers carry another's diamonds for consignment. Similarly, some merchants with family connections are also deeply embedded within the Orthodox community and are motivated by the same community institutions that constrain brokers. However, brokers, or those without a stake in a family business, are overwhelmingly from the ultra-Orthodox community, as every merchant is constrained either through intergenerational incentives or through community institutions.

44. Berman (2000) describes a process where one generation accumulates capital specifically so their children can engage in full-time religious study well into their productive adult years. 
The important observation is that members from these very different groups are motivated and constrained by different forces. All parties engage in a type of time-inconsistent exchange in which delivery of the diamond precedes any payment. But, since the parties are from two very different groups, they are connected to different community institutions, are constrained by different individuals or institutions, have different business incentives, and have different preferences. Consequently, distinct mechanisms are required to induce the two types of parties to comply with their contractual obligations. What induces one group to cooperate cannot explain the behavior of the other.

\section{Long-Term Players}

Though dealers and buyers rely on different industry skills and occupy different locations in the distribution system, a key commonality is that both are long-term players in the industry. Sellers have a steady supply of diamonds they need to sell, and buyers, most of whom are jewelry manufacturers, rely on being able to purchase precious stones to keep up with demand. Following the iterated Prisoner's Dilemma paradigm, this long-term market participation allows the prospect of future sales to induce cooperation for current sales.

The diamond industry introduces two important complications to the simple Prisoner's Dilemma. First, the industry involves many players who do not necessarily know with whom they will transact in the future, so the prospects of future dealings with a current business partner are not sufficiently certain to induce multilateral cooperation. The second is that the extreme value of diamonds may require an unusually credible mechanism to assure endless exchange (a solution to the end-game problem) and a very low discount rate to support cooperation. These complications are addressed in turn.

\section{Sustaining Multilateral Cooperation}

For cooperation to be sustained when there are many industry players, each player must always be induced by the prospect of future business with other players. In other words, when a player transacts with business partner $(B)$ in time period $(t=0)$, he must be induced by the prospect of future transactions with partners $(\neq \mathrm{B})$ in periods $(t>0)$. This is accomplished by a reputation mechanism. If each player's past dealings are known, such that all potential business partners know whether a certain merchant has cheated in the past, and all merchants refuse to transact with an individual who has cheated, then all players will be sufficiently induced to 
cooperate, even with business partners with whom they will never do business again. ${ }^{45}$

Illustrating how a reputation mechanism can induce cooperation under these conditions does not require a complex mathematical proof. Individual players will cooperate so long as the system promises that their long-run returns will exceed the potential profits from cheating. The burdensome features of the proof are its very demanding conditions: widespread information, accurate information, and coordinated punishment. ${ }^{46}$ These conditions enable a reputation mechanism to support multilateral exchange.

The diamond industry has all three. The DDC educates dealers about potential business partners by supporting information networks in which dealers share valuable information with each other, and the Club's arbitration committee disseminates its decisions and publicizes the names of those it has determined have not complied with their obligations. ${ }^{47}$ As a result of these information mechanisms, any member can research the past of a potential business partner and can learn whether he was noncompliant in a previous transaction.

The reliability of reputation information, not just its dissemination, is also crucial to ensure proper incentives to cooperate, and thus several forces complement information sources to ensure their veracity. One source of guaranteeing accuracy is the DDC's arbitration board. The arbitration board is comprised of insiders who are extremely familiar with the nature of the industry and the difficulties involved in entering diamond contracts. Their expertise helps arbitrators understand the context within which disputes arise, distinguish meritorious from nonmeritorious claims, verify the veracity of proffered evidence, and, when appropriate, estimate the appropriate damages. Additionally, the board may respond to misinformation and punish any party responsible for spreading inaccurate information about another's reputation. ${ }^{48}$

45. The basis for this model is found in Milgrom, North, and Weingast (1990). Kreps (1990) offers another important model that rests on similar logic but emphasizes bilateral rather than multilateral repeat interactions. For a historical example involving cross-continental medieval trade, see Greif $(1989,1993)$.

46. Given these demanding conditions, some scholars are more skeptical than others over the viability of reputation-based systems of private ordering. Compare Kreps (1990) (presenting a model for reputation mechanisms) with Williamson (1991, 167-69) (detailing the rigorous requirements to support trust-based exchange and the many factors that could disrupt such exchange systems).

47. See notes 35-37 and accompanying text above.

48. In one case, a dealer falsely accused another of stealing his stone. He later realized that he actually misplaced the stone and apologized to the dealer, but the accusation had already become common knowledge. The second dealer then brought the first before the arbitration committee for impugning his reputation, and the board ordered the false accuser to make a public apology and donate $\$ 50,000$ to a Jewish charity (Bernstein 1992, 127). 
Another force working to ensure the accuracy of reputation information is the rigorous set of Jewish laws that strictly regulate the information one is permitted, prohibited, and required to disclose regarding another individual. For example, Jewish law forbids individuals from knowingly disseminating false and damaging information about others, and it also requires individuals to have compelling reasons for sharing information that, even if truthful, is damaging or unflattering to another. ${ }^{49}$ Jewish law does not, however, place excessive barriers to communicating reputation information that prevent a merchant from obtaining the information necessary to sustain his livelihood. To the contrary, Jewish law mandates the sharing of damaging yet truthful reputation information if such information would be of substantial use to the recipient, so long as it is not exaggerated, is shared only because it would aid the recipient, and is shared only to the degree necessary to assist the recipient (Broyde 1996). These religious rules help filter communications to increase their accuracy-deterring the spread of misinformation and unnecessary information-without unduly preventing the dissemination of useful information. In a world where good reputations are so critical to commercial success, and where gossip can be so damaging, these filters are important in discouraging aimless information of questionable veracity.

The third condition for an effective reputation mechanism is to credibly ensure that the expected benefits of cooperation will exceed the expected benefits from cheating, or put otherwise, that a cheater will be sufficiently punished so that cheating is less attractive than cooperating indefinitely. The industry punishes such cheaters by exacting coordinated punishment, such that all merchants refuse to do business with a merchant who has failed to comply with a contractual obligation in the past. A merchant who has failed to pay a debt or refused to comply with an arbitration ruling will be expelled from the DDC, find his transgression publicized, and fail to obtain future business. Conceivably a past cheater, after acquiring a bad reputation and finding that normally available business opportunities are foreclosed, might offer a premium to a merchant to convince him to do business (in which the cheater's losses from selling at discounted prices could be less than the one-time gain from cheating). Yet because industry reputations extend not just to a merchant's actions but also to the identity of his business partners, a merchant's own reputation may suffer if he is known to transact with previous cheaters. Moreover, given the strong demand for transactional security, merchants generally do not assume the danger of extending credit to individuals who they know have failed previously to comply with payment obligations. Since past cheaters enjoy fewer business opportunities than

49. Jewish law imposes three distinct prohibitions: knowingly communicating false, negative statements about another (motzi shem rah); making unflattering, but true, remarks about a person for no reason (lashon harah); and recounting to a person gossip heard about him (rekhilut) (Broyde 1996, 77 [citing Maimonides, Deot 7:1-7]). 
honest brokers, they have less incentive to sustain cooperation and thus pose greater risks. ${ }^{50}$

\section{Securing an Infinite Time Horizon and a Low Discount Rate}

If cheating brings extreme one-time rewards, even the threat of banning an individual from all future diamond transactions may not be enough to force compliance. Moreover, individuals present an end-game problem if their participation in the trade reaches an inevitable end. Cooperation is sustained only if parties have an endless future of exchanges and an unlikely low discount rate. ${ }^{51}$ The diamond industry's consistent presence of family-based firms accomplishes both of these. The intergenerational nature of the family firms extends the time horizon for cooperation beyond the limited lifespan of an individual dealer. So long as a diamond dealer is concerned about his family's reputation and not just his own, he will continue to have incentives to cooperate even if he plans to retire soon. Parties would only cheat if they knew there were a finite number of future transactions.

For this mechanism to work, reputation information has to be familyspecific, not just individual-specific. This is, in fact, how reputation operates in the diamond trade. While an individual is trusted and receives business based on his reputation, a young dealer inherits the reputation of his family mentor. Part of this is because the elder sponsors the young relative during his early dealings (by explicitly promising to cover any losses anyone incurs by dealing with the young relative), but an individual's family connections and associations are very important in attracting business trust even when that sponsorship ends. The DDC Bylaws, which impose easier membership requirements for spouses, widows, sons, daughters, and sons- and daughtersin-law of current members, also reflect how extended family relationships extend trustworthiness (DDC Bylaws, Art. 3, §§ 2a, 3b). Reputation capital can also extend beyond the immediate family, as cousins, nieces, and nephews of respected dealers enjoy some initial trust when they enter the industry.

50. While reputations are fragile and extremely difficult to recover once damaged, rehabilitation is sometimes possible if a well-respected industry member offers assistance. In some instances a merchant who has failed to comply with a commitment he made consequently has suffered harm to his reputation, an elder merchant-motivated as much by compassion as by profit—will agree to a deal with him in order to rehabilitate the failed merchant's reputation. This reflects the balance between the serious need to deter cheating with the compassionate recognition that individuals have human frailties. It also is consistent with models of cooperation in which entry costs, or gift giving, are required before entering into a trust-based network of exchange (Carmichael and MacLeod 1997).

51. Some diamond dealers enjoy sizable incomes (De Beers wants to maintain stable downstream distributors and shares some of its monopoly rents with dealers), suggesting that the threat of individual sanctions, without an infinite time horizon, might be sufficient to induce cooperation. Nonetheless, the end-game problem-presented as each long-term merchant approaches the end of his career-forces the diamond industry to develop a creative solution to the Prisoner's Dilemma paradigm. 
The value of a family's reputation has three important economic implications. First, individuals supported by a family reputation have an important advantage over otherwise identical entrepreneurs who have no family connections, creating a powerful barrier to entry to outsiders. Certainly, the vast majority of entry-level positions are acquired because of family connections, but family reputations remain important throughout one's career. New acquaintances are introduced in reference to their family, and thus new business opportunities are either created or foreclosed by the quality of one's family reputation, and prospective entrepreneurs without family sponsorship or introductions are routinely met with deep skepticism and distrust. Second, and most obviously, the family-based nature of businesses secures future riches for relatives who currently hold entry-level positions. Young relatives-employees who handle their elder's diamonds have the very reasonable expectation that they will inherit the business. This is enough to make their individual time horizons very long and induce them to cooperate. And third, and the economic consequence most critical to sustaining cooperation for multiple generations, reputation can be both bequeathed and leveraged. If a leader of a family business has a good reputation, he can bequeath the reputation to several descendants. Accordingly, the elder merchant is motivated by the prospect of a larger number of future transactions than just the number he would execute if he lived forever. So an individual's imminent retirement is no cause for an end-game problem. In fact, the opposite may be truewhen a dealer nears the end of his career, he knows that his reputation will influence the transactions of several relatives. This premium on future transactions is critical to sustain cooperation in the face of large returns from one-time defections.

Significantly, the role of Jewish community institutions in sustaining multi-generational cooperation is mostly secondary to the importance of family connections and industry rules. Jewish norms and the intimacy of the Jewish community play valuable functions in spreading information among industry players and in coordinating punishment, but the Jewish community is not alone in its ability to spread accurate information. The only irreplaceable aspect of long-term players is their predominant tendency to be connected to intergenerational family businesses, and that feature is by no means exclusive to the Jewish community. ${ }^{52}$ The value of family here is paramount, and the value of the ultra-Orthodox participation is necessary only for short-term players.

\section{D. "Diamond Studded Paupers"}

The ultra-Orthodox brokers and cutters, who constitute the second category of diamond merchants, provide important value-added services and

52. See Section V below (discussing intergenerational Belgian and Indian family firms). 
are critical in making the diamond industry profitable. However, since they are much less likely to bring their descendants into the diamond trade, the prospects of future exchange are insufficient to induce them to cooperate. In fact, because of their commitment to ultra-Orthodox Judaism and their love for traditional religious learning, they would like nothing more than to stop working and engage in full-time study. Their rewards for cooperating must take effect within a much shorter time period.

Two additional important features characterize these workers. First, unlike the successful dealers and jewelry manufacturers, they are not wealthy people. Though this is easily explained by their low skills set and the very competitive labor market for unskilled brokers, it is nevertheless remarkable given the industry in which they work: these workers have lots of diamonds, but no money. The consequence is startling. Scores of diamonds fall from these workers' fingertips, yet they are dressed in tattered clothes.

Second, these workers operate with a tremendous degree of informality. Contracts are informal, and many operate their businesses without paper records. A diamond cutter, for example, will have piles of diamonds before him, each wrapped in a small piece of paper and placed in an envelope. Clients will drop off such envelopes, with the owner's name written on the outside and some cutting instructions inside, then leave without a verifiable record that their valuable cache of diamonds are in another's possession.

For these workers, the attractiveness of theft (given their low wages) and the ease of theft (given their informality) belie a simple profit maximization model and demand a more complicated utility theory to explain sustained cooperation. One useful model that can explain seemingly noneconomic behavior, and one that has been employed by scholars of religious sects, is a "club good" model (Cornes and Sandler). ${ }^{53}$ In clubs, members have preferences for both standard consumption goods and excludable club-specific goods, and their utilities are determined by a joint function of both goods. Club goods are available only in the club, only club members can consume club goods, and each member of the club experiences externalities from every other member's behavior. Consequently, club members strive to obtain club goods just as they would standard goods, and relatedly, the club (or community) will manipulate the consumption of club goods in order to induce behavior that is desirable to the club. ${ }^{54}$

53. Berman (2000) uses the club good model to explain several seemingly uneconomic practices in the ultra-Orthodox community, including the expenditure of significant family resources and time to practice religious rituals.

54. In a club good model, a club member's utility is $U_{i}=U\left(S_{i}, R_{i}, Q\right)$, where $S$ are normal goods, $\mathrm{R}$ are club goods, and $\mathrm{Q}$ reflects the average consumption of club goods by other community members, or $\Sigma_{\mathrm{i} \neq \mathrm{j}} \mathrm{R}_{\mathrm{j}} /(\mathrm{N}-1)$ for a community of $\mathrm{N}$ members. Other conditions include $\partial \mathrm{U}_{\mathrm{i}} / \partial \mathrm{S}_{\mathrm{i}}$, $\partial \mathrm{U}_{\mathrm{i}} / \partial \mathrm{R}_{\mathrm{i}}, \partial \mathrm{U}_{\mathrm{i}} / \partial \mathrm{Q}>0$ and $\mathrm{U}(0, \bullet, \bullet)=\mathrm{U}(\bullet, 0, \bullet)=\mathrm{U}(\bullet, \bullet, 0)=0$ (Iannaccone 1992; Berman 2000).

The conditions $\mathrm{U}(\bullet, 0, \bullet)=\mathrm{U}(\bullet, \bullet, 0)=0$ mean that a community member will avoid excommunication from his community at all costs, just as he will strive to avoid poverty and deprivation of standard goods. Specifically, a diamond thief will derive zero utility from priceless stolen diamonds if stealing them means he will have to live away from his fellow Orthodox Jews. 
The club good model goes far in explaining the important role of the ultra-Orthodox in the diamond trade. First, community members' appetite for community goods, which by hypothesis are available only in the community, ${ }^{55}$ explains why brokers pose no risk of flight. Departure from the community would reduce a member's consumption of club goods to zero and cause a loss in utility that is not overcome by the riches from a stolen cache of diamonds. Consequently, ultra-Orthodox brokers and cutters are able to credibly commit to safeguarding a merchant's diamonds.

Nevertheless, and though it is rare, flight is not unprecedented, and ultra-Orthodox communities do occasionally watch some members leave for less observant communities or other ultra-Orthodox sects. Accordingly, diamond merchants will look for other assurances that suggest a diamond contractor is fully embedded within the community and thus committed to cooperation. Ultra-Orthodox community institutions do much of this filtering themselves. For example, males generally remain full-time students of religious studies for several years after getting married and beginning families. ${ }^{56} \mathrm{By}$ the time a male completes full-time study and is ready to assume economic responsibilities, he already has a spouse and children entrenched within the community and thus is far less likely to depart. Such entwinement within the community serves as an additional commitment device.

Another important feature of the club good model is that the whole community is motivated to ensure that each member engages in desirable behavior. ${ }^{57}$ For the ultra-Orthodox, this means the community is invested in ensuring that its members involved in the diamond industry fulfill their contractual obligations. The credibility of its members certainly brings wealth

55. It is worth noting that there are many different ultra-Orthodox sects, each with its own fairly self-contained community. One distinction that separates ultra-Orthodox communities is the division between the Hasidim (literally, "pious ones"), who emphasize a spiritual and pietistic observance, and the Misnagdim (literally, "opponents" [of Hasidim]), who emphasize a stricter legal and academic observance. Other subdivisions further distinguish communities from each other, including the Lubavitch, Satmar, and Belzer sects of Hasidism. While these divisions among the ultra-Orthodox have been diluted as the common threats of secularism and less observant movements of Judaism gained popularity, these distinctions continue to thrive (Heilman 1992, chap. 2). Consequently, though the world is home to many ultra-Orthodox communities, the heterogeneity compels community members to remain in their original sects.

56. Berman (2000) discusses the conflicting pressures to commit many years to study while fulfilling the biblical commandment to "be fruitful and multiply" by marrying young and having many children. A young couple frequently will live with their in-laws for several years or will receive community stipends until the male completes his religious study, which often continues until he is forty years old. Several similar commitment devices signal to community leaders who among their young adults are worthy of economic support.

57. In the formal depiction of the club good model, see note 54 above, the variable Q-reflecting the average consumption of club goods in the community - is in each member's utility function and is constant throughout the community. It thus motivates the entire community to encourage its members to pursue certain behaviors since each individual's consumption affects every community member's utility. As a consequence, the community will establish certain norms and institutions that will induce club-good consumption. For the ultra-Orthodox, this includes contract compliance. 
to the community, ensuring sustained income for its current workers and its younger members, but it also reflects an adherence to values that have religious significance to the community and, according to the club good model, add to each members' utility. ${ }^{58}$ Consequently, the community does not rely on its diamond workers to police themselves and instead employs community institutions to enforce diamond transactions. ${ }^{59}$

One community enforcement instrument is to use rabbinical courts to impose sanctions. The harshest of all punishments is the excommunication of an offender, which is not unprecedented but which is an extremely severe and rare penalty. ${ }^{60}$ Rabbinical courts are more likely to impose less severe measures, such as stripping an individual of a community honor or an order to compel an individual to make a charitable contribution to a community charity. The DDC arbitration committee itself can initiate a proceeding in a rabbinical court, and the close connection between the two forums illustrates the diamond industry's reliance on community institutions to help enforce contracts.

Less formal institutions also play a role in enforcing contractual compliance. When the community is familiar with a member's failure to comply with contractual obligations, religious leaders often withhold excludable community goods, such as participation roles in daily prayer, honors in lifecycle ceremonies, access to classes or teachers that are in limited supply, or enrollment in particularly select educational institutions. Implicit in all these

58. Jewish commandments involving economic behavior are not explained in Jewish legal texts by norms of efficiency, but instead rest purely on ethical and religious justifications (Baron 1975, 49-54). Consequently, adhering to the Jewish commandment to fulfill contracts, apply accurate weights and measures (the doctrine of "just price"), or charge only fair prices (the theory of "misrepresentation") were akin to fulfilling oaths before the divine.

59. The ultra-Orthodox community uses coordinated sanctions and the denial of community goods to force other behavior, in addition to certain economic behavior, that state courts cannot induce. One prominent and controversial example is the plight of the Agunah, or "chained wife," the woman who is separated from her husband but has not yet secured a divorce. According to Jewish law, wives cannot unilaterally divorce their husbands, and previously married women cannot remarry unless their husbands grant them a religious divorce. Many husbands refuse to grant the religious divorce either to extort concessions from their wives or simply to spitefully exercise control over their wives' personal lives. Consequently, some communities mobilize to compel husbands to grant their wives divorces (Jackson 2001). Many such compulsions include employing the power of secular courts, but others include the denial of community honors or synagogue participation and more draconian compulsions such as physical force and threats of violence. These are the same enforcement mechanisms that assume economic importance in the diamond industry. For a personal perspective of the plight of the Agunah and resources for Agunot, see http://www.agunot-campaign.org.uk/index.htm.

60. Bernstein (1992) reports that the DDC arbitration board initiated an excommunication proceeding against Martin Rapaport, the diamond dealer who began the Rapaport Diamond Report (see note 36 above).

Many ultra-Orthodox communities also bundle religious rights with financial claims, which prevents a community member from leaving his community with his property. These concerns make the threat of excommunication all the more powerful. Broyde (1998) describes both how Jewish law administers the rites of excommunication and argues how secular law should respond. 
specific goods is community respect, which certainly brings an individual direct utility but which is also expressed through the assorted community rituals. One significant expression of community respect pertains to how easily-and with how prominent a family_parents can arrange their children's marriage. Arranged marriage is the norm in many ultra-Orthodox communities, and a family's community status is often a leading factor in determining with whom they arrange their children to marry (Heilman 1992, 277-86).

Importantly, Orthodox Judaism is replete with concrete, identifiable community goods that have subtle hierarchies. Small distinctions can translate into either valued honors or disappointing slights, and the large number of religious goods offers community leaders a broad menu of punishment options with an assortment of severity. Community leaders can tailor punishments to match the severity of the harm done, bringing about the desired deterrence without expending community resources.

The remarkable features of these community enforcement mechanisms is not that they work perfectly-no enforcement system is perfect, and the Orthodox community experiences theft as do all others-but that they are intimately intertwined with the natural community fabric. Ethical business behavior is, simply, ethical behavior, and an honorable businessman is an honorable community member. There appears to be nothing inherently Jewish about these values, but Jewish law and the community's system of disbursing excludable community religious goods has become intimately enmeshed with the enforcement needs of the business world. Such a combination of institutional complementarities has created a remarkably effective system. While dealers acknowledge that there have been and will continue to be merchants who cheat, make mistakes, or somehow deviate from their contractual obligations, these occurrences are extremely infrequent given the quantity of transactions and the amount of credit in which merchants engage. The ultra-Orthodox have managed to institute a remarkably effective system without measurably adulterating their religious community. ${ }^{61}$

\section{E. Summary and Implications}

To summarize, New York's diamond merchants can be divided into two groups. Long-term players enter the industry through family connections and are induced to cooperate because maintaining a good reputation invites the promise of inheriting the family business and later bequeathing it to their descendants. Independent contractors who do not have the prospects of

61. Note that the ultra-Orthodox community punishes its own members even if the victim is a non-Jew, and more generally, communities in the diamond industry police their own members even if they cheat outsiders. This is because maintaining the community's credibility in dealings with outsiders brings wealth to the whole community (Greif 2004). 
family legacies come overwhelmingly from the ultra-Orthodox community. They comply with their contractual obligations because failing to do so would lead to the denial of excludable community goods. This combination of family-based reputation mechanisms and community-based enforcement institutions allows New York's diamond merchants to organize reliable timeinconsistent exchange.

The implications of this two-pronged system of enforcement are that all players who are trusted with another's diamonds must belong to one of the two categories and be subject to its respective punishment devices. The system embodies what Yoram Ben-Porath (1980) called "the F-Connection," whereby trade networks organized around families and friends can execute informal contracts that enjoy efficiencies unavailable to formal, arm's-length transactions. Certainly, the success of the ultra-Orthodox in enforcing informal contracts mirrors the success of other ethnically homogeneous communities who have built prosperous networks of commerce without relying on formal court ordering, ${ }^{62}$ and some have generalized to construct a comprehensive theory on the "Ethnically Homogeneous Middleman Group" (EHMG) (Landa 1981). Leaving tempting generalizations aside, this article illustrates how family and ethnic networks enable New York's diamond industry to prosper despite the ineffectiveness of public courts.

\section{RELATED PHENOMENA OF PRIVATE ENFORCEMENT}

Since diamond transactions present the same contracting challenges regardless of the identity of the transacting parties, all diamond centers must devise mechanisms to enforce those transactions. Similarly, since diamonds are not the only commodities to present these contracting challenges, trade networks that successfully traffic diamonds should succeed in other industries that present similar contracting difficulties. These twin implications present testable hypotheses. If either a family or a community connection were required to support diamond credit sales in New York, then similar family or community institutions (though not necessarily Jewish institutions) would be present in other diamond centers as well; and if Jewish networks can enforce diamond credit sales, then they should also excel in enforcing other transactions that lie beyond the reach of public courts. This section briefly discusses related instances of private ordering, and though it only offers an inspection much more cursory than the detailed examination provided above for New York's diamond industry, and hopefully future research will provide more detailed inspections, it finds important—albeit preliminary-support for the above hypotheses.

62. One prominent and well-studied example is Chinese family businesses in Southeast Asia (Dewey 1962; Belshaw 1965; Weidenbaum and Hughes 1996). 


\section{A. Mumbai}

Indian merchants have recently entered and prospered in New York's diamond industry. But, even though they are relative newcomers to New York's market, Indian merchants have traded in diamonds for nearly two and one-half millennia. From the world's first discovery of diamonds in 800 B.C. until diamond finds in Brazil in 1844, the Indian subcontinent was the world's only source of diamonds. But despite this long history, Indian diamond merchants did not have a major impact on the global market until the mid1970s. Only then did Indian diamond merchants translate their diamond expertise into major cutting operations that, one decade later, developed into lucrative global trading networks. ${ }^{63}$ Now, Mumbai is home to an active bourse, and thousands of cutting factories populate nearby Gujarat province. ${ }^{64}$ Over 700,000 Indians work as diamond cutters, polishing nine out of every ten stones sold in the world (Oppenheimer 1999; Kripalani 2000) ${ }^{65}$

Like their Jewish counterparts, Indian diamond merchants rely on both family and community connections to support their trading networks (Dotson and Dotson 1968). Family networks are evident in each Indian company, and Indian family businesses stretch from Mumbai into the world's other cutting and distribution centers (Piramal 1990). ${ }^{66}$ And because a small ethnic minority has dominated India's diamond industry, community and tribal foundations are equally prominent. For centuries, the Jains of Palanpur, a religious minority from a parched, dusty village in Northern Gujarat, ${ }^{67}$ have served as India's diamontaires. Today, over 95 percent of the 2,400 members of India's Gem and Jewelry Export Promotion Council and the leaders of all seven of the nation's largest companies, which control 25 percent of the country's diamond exports, are Palanpuri Jain.

In addition to the Palanpuris, a second ethnic sect is active in the diamond industry. Angadias, which in Gujarati means "one who carries

63. In recounting the early growth of India's diamond industry and the establishment of large cutting operations specializing in small stones, Bharat Shah, founder and chairman of India's largest private empire (and a multibillionaire), boasted "We went to the bottom end of the market, buying and cutting diamonds which the Jews had rejected" (Piramal 1996).

64. Diamond cutting factories can employ workers outside family and community networks, and thus transfer to low-wage countries, because a firm's hierarchical controls are able to govern diamond transactions within the factory (Richman 2004; Williamson 1985). Historically, diamond merchants have profitably moved diamond cutting ventures away from diamond centers and to countries as diverse as China, Brazil, and Cuba while successfully managing the dangers of employee theft (Federman 1985).

65. Note that this statistic reflects the number of stones cut, not the market share value they represent (which is substantially less than 90 percent). Also, this figure further overstates the role of India's cutting since some stones are polished several times in different locations.

66. One diamond merchant lamented, "This business demands personal attention and trust. Only your family can give both. I have remained a small diamond exporter because I do not have a brother whom I can send to live in Antwerp" (Piramal 1990).

67. Jainism, a religious and philosophical tradition that is close to (and perhaps has rise to) Buddhism, accounts for 0.4 percent of all Indians. See http://en.wikipedia.org/wiki/Jainism. 
valuables" or "trustworthy person," serve the important role of transporting diamonds from the Mumbai to Gujarat for cutting. Angadias are recruited only from the Patel community in Gujarat's Mehsana district and have traveled the Mumbai-Gujarat route for more than 125 years, beginning with camel caravans and now traveling third-class on express trains (Hazarika 1985). ${ }^{68}$ Like the ultra-Orthodox, both Angadias and the Palanpuris are described as very tightly knit, secretive, and insular communities (Hazarika 1985; Karp 1999; Kriplani 2000), ${ }^{69}$ and like the ultra-Orthodox, both communities have harnessed their community structure to excel in diamond centers (Piramal 1990; 1996).

The structure of the Indian diamond networks provides useful corroborating evidence that community institutions are responsible for success in the diamond industry. Indian and Jewish merchants have both achieved prominence through similar mechanisms-family businesses and ethnic networks-but have done so on different continents and with separate histories. Moreover, both communities have maintained their networks despite recent vigorous competition with each other. In the face of global competition, these traditional community structures have proven to be economic assets, not historical vestiges.

\section{B. Antwerp}

Diamond merchants began importing diamonds to Antwerp in the late fourteenth century, and Antwerp's leadership in diamonds came in the fifteenth and sixteenth centuries when Jewish cutters were expelled from Spain and Portugal and fled to Antwerp and Amsterdam. It has been a global diamond capital since 1870, when Belgium's colonial roots enabled the country's merchants to take advantage of lucrative diamonds discoveries in South Africa, and today's Antwerp and its four interconnected bourses are the first stop for most uncut diamonds. Eight out of ten of the world's uncut diamonds and one in two polished diamonds pass through Antwerp, generating $\$ 36$ billion in exports in 2004 (Fullerton 2005).

Of all the world's diamond centers, Antwerp most closely resembles New York. The city's diamond trade is dominated by approximately 1,600 familybased companies whose members largely belong to three distinct ethnic groups: native Belgian, Jewish, and Indian. The Indian traders, nearly all Palanpuri Jain, are relatively recent arrivals, but their family and ethnic networks now constitute approximately two-thirds of Antwerp's diamond trade. Jewish and

68. A typical troupe of thirty Anagadias-plainly dressed, unarmed, and carrying unmarked canvas sacks_-will transport $\$ 4$ million in diamonds each day while earning salaries of less than $\$ 50$ a month.

69. One courier was noted, "Anagadias like me will bring only persons that we know into the business because our personal honor and career is at stake” (Karp 1999). 
Belgian family businesses, both still important players, have longer histories in the country, with many Belgian families tracing their roots to the original traders in Bruges, and have relied on intergenerational legacies to sustain their diamond businesses.

Also like New York's trade, Antwerp's brokers and cutters historically have been predominantly ultra-Orthodox Jews. In the beginning of the twentieth century, Jews constituted three-quarters of the city's diamond brokers and an even higher percentage of the factory owners, and the city's large ultraOrthodox Jewish population led Antwerp to be known as the "Jerusalem of the West" (Abicht 2000).$^{70}$ Today, cutting factories in India, enjoying cheaper labor costs, have supplanted most of the cutting in Antwerp, and the city has seen its peak of 30,000 cutters fall to just 800 specialized polishers. These changes have also led Indians to constitute a majority of the Antwerp market (Simons 2006). Nonetheless, Antwerp remains an important diamond center, and despite its significant changes, the city continues to rest on intergenerational family businesses and a large presence of ethnic brokers.

\section{Israel/Palestine}

Israel's cottage diamond industry experienced its first significant growth during World War II, when Palestine became a refuge for Jewish diamond merchants during the German occupation of the Netherlands and Belgium. Israel's diamond industry suffered briefly during the years leading up to its War of Independence in 1948 (which, in part, helped Antwerp regain its prominence after World War II) but again experienced rapid growth in the 1950s and became the world's largest exporter in the early 1980s.

Israel's current diamond industry has many of the same features present in the other diamond centers, particularly New York. Diamond companies are family-based companies, and Israel's diamond bourse, the Israel Diamond Exchange, will now only admit new members who are relatives of current members. Also like New York, many ultra-Orthodox occupy the Diamond Exchange, serving as brokers for large diamond merchants, and between 30-40 percent of all Exchange members are ultra-Orthodox. Here too, family relationships and the ultra-Orthodox community are both important components in operating the industry.

The development of Israel's diamond cutting industry, however, reveals a slightly different institutional picture than those in other centers. Israel's early industry grew on refugees and immigrants who started with jobs in small cutting facilities; after these new arrivals acquired industry knowledge and skills, they opened their own small operations with a small collection of newer

70. For a nice, and not entirely obsolete, discussion of Antwerp's Jewish community, and its involvement with the diamond industry, see Gutwirth (1968). 
immigrants. Thus, unlike Israel's current industry and unlike conditions in other centers, Israel's early growth offered opportunities for entry. This appears to be a small exception to the requirement of a family or community connection.

It is tempting to discount the brief period of entry to extenuating circumstances. During Israel's early years, the industry was growing rapidly and was in desperate need for new labor to support a promising industry in an otherwise struggling economy. Also, Israel was home to thousands of World War II refugees who were desperate for work, and several Israeli government agencies actively searched for new sources of diamonds to buttress the country's emerging polishing trade. But since economic desperation might exacerbate, not reduce, diamond contracting challenges, a better explanation probably lies in Israel's unusual historical context in its early years. Many diamond workers were World War II refugees who posed only the remotest risk of fleeing the country and, especially in the small and intimate nation, would have trouble hiding. Moreover, the aftermath of the Holocaust possibly created a strong, pan-national spirit that could have advanced both trustbased relationships and social enforcement mechanisms. Even so, the leap from family and community relationships to broader national connections is a difficult one to make. To be sure, the early days of the State of Israel were unique, and the nation's diamond industry during those years appears to be a narrow exception to the family-community hypothesis.

\section{Jewish Merchants and Private Ordering}

The same family and community networks that benefit Jewish merchants in the diamond trade should also provide a comparative advantage in other industries in which contracts lie beyond the enforcement of public courts. Jewish economic history offers several instances that support this implication.

Before modernity introduced reliable court-enforced contract law, Jewish merchants historically traded in small, portable, and valuable commodities, including money. In the Middle Ages, Jews were prominent in the trade for expensive dye-stuffs, such as reseda, saffron, and indigo (Baron 1975, 162-63). Jewish craftsmen also excelled working in fine metals, and Jewish goldsmiths found success in twelfth century Egypt, Iraq, Persia, Yemen, and Maghreb, fifteenth century Spain and Portugal, and seventeenth century Central Europe (Baron 1975, 164-65). ${ }^{71}$ But above all other commercial activity, pre-Enlightenment Jewish businessmen engaged in banking and money lending. ${ }^{72}$ Jewish bankers emerged in Baghdad in the ninth century because they were able to

71. Baron (1975), consistent with the views expressed in notes 6-7 above, offers: "That this was a widespread Jewish occupation in Muslim countries may be explained by the contempt in which artisans were held by the Arabs."

72. Cecil Roth (1961b) writes, "The Jew was the classic money-lender of the Middle Ages, and the classic profession of the medieval Jew was money-lending." 


\section{LAW \& SOCIAL INQUIRY}

collect and invest the savings of the whole Jewish merchant class (as opposed to the savings of a few rich individuals, which at that time was a far more common banking practice). Europe saw its first Jewish bankers within the administration of the Merovingian Kings in AD 481, and for the five centuries following the rise of the First Crusade, Jews turned chiefly to loan-banking for sustenance (Emery 1959; Roth 1961b; Arkin 1975, 57-63).

For small portable goods of such high value, credit sales are extremely vulnerable to nonpayment, so the successful merchants were those who could consistently collect payment (and similarly, those who could credibly commit to pay). Since the social structure of the Jewish community before the Enlightenment in the eighteenth century was insular, intimate, and fostered interdependency — very similar to today's ultra-Orthodox community-it is likely that community institutions and norms were critical in governing these trades.

Family and community networks can also offer lucrative opportunities in modern markets in addition to the diamond trade. One such opportunity is trade in illegal goods, since sales contracts for illegally traded goods are not enforceable in public courts. And, in fact, several Jewish diamond merchants have employed their community institutions to profit from illegal goods. In 1999, for example, Russian authorities apprehended several ultra-Orthodox Jews for illegally smuggling assorted goods from the country, including diamonds and antique Hebrew books (JTA 1999). More dramatic, the New York Daily News reported that Israeli drug dealers harnessed Jewish diamond networks to smuggle Ecstasy into New York, where ultra-Orthodox couriers typically transported 30,000 to 45,000 pills and as much as $\$ 500,000$ in drug proceeds (Katz 2001, 89-91).

Jewish merchants would not have found success in these other trades had they been unable to enforce executory contracts that lay beyond the public courts. The sources of success for modern-day Jewish diamond traders mirror the sources of success for these other Jewish merchants throughout history.

\section{CONCLUSION}

Jewish predominance in the diamond industry is explained by the community's ability to enforce contracts that are unenforceable for other merchants. Intergenerational family firms enable reputation mechanisms to enforce cooperation among long-term dealers, and intimate community institutions police the behavior of short-term, independent players. The result is a system of reliable contractual enforcement that permits sales on credit and leads to a rejection of public courts. Community institutions are central in explaining both the industry's infrastructure and the industry's leaders.

The particularly interesting feature of this system is the economic role of ultra-Orthodox Jews. The ultra-Orthodox provide critical value-added 
services that add significant efficiency to the system of exchange. They work as skilled diamond cutters whose polishing increases the sale prices of stones, and they play the essential role of middlemen brokers who match certain stones with the buyers who most value them. Their unique credibility provides the Jewish merchants with a comparative advantage over rival merchant groups that lack such community foundations, and their role identifies limitations to public contract enforcement that persist even in developed economies. When courts fail, community institutions can arise to fill their place. ${ }^{73}$

However, the end of the ultra-Orthodox's role in the diamond trade may be at hand, as two recent developments may irreversibly change the diamond industry and obviate the contributions the ultra-Orthodox make. The first is the utilization of low-cost labor to cut and polish diamonds. Prior to the explosion of Indian cutting factories, diamonds were chiefly polished in Antwerp, New York, and Israel by family businesses and independent cutters. Now, while cutters in those diamond centers still polish many of the largest and most valuable stones, small stones, which comprise a vast majority of cutting activity, are polished in large factories in India and Southeast Asia. Antwerp's and Israel's cutters are now a fraction of their former glory-over the last two decades, Antwerp has lost nearly 90 percent of its cutting jobs and Israel approximately 70 percent. Indian and Chinese laborers are assuming the positions long held by the ultra-Orthodox, and technological innovations, mostly in the form of cutting machinery that replaces skilled labor, will accelerate that trend.

A second development is De Beers' new marketing strategy. In July 2000, De Beers, facing a decline in its market share and a corresponding dilution of its monopoly rents, announced plans to brand its diamonds and market them directly to consumers with a promise that each diamond has identical qualities. A cornerstone of the company's plan was forming a joint venture in early 2001 with LVMH Moet Hennessy Louis Vuitton, a French luxury goods conglomerate, to market "designer diamonds" that exhibit unusual shapes and designs. In addition, De Beers is requiring its sightholders to devise similar strategic plans to market brand diamonds to high-end consumers (Weber 2001). ${ }^{74}$ If these marketing strategies work, then consumers will be able to purchase a diamond like any other commodity and will bypass the entire search process in which brokers match buyers with specific stones. Similar strategies are being pursued by some Internet diamond brokerages. Web sites list an inventory of diamonds with GIA-certified features and a high-resolution picture, and interested buyers negotiate directly with owners without intervening middlemen. Even though many merchants remain

73. For a more formal model predicting when the limitations of public courts will induce merchants to pursue private ordering, see Richman (2004).

74. Some designer diamonds have already emerged, such as the Escada Diamond with 97 facets (the traditional diamond has only 58) and the patented Leo Diamond with 66 facets. 


\section{LAW \& SOCIAL INQUIRY}

skeptical that a picture and GIA categories can relay sufficient information about a stone, Internet sales are growing and by one statistic already comprise 15 percent of all sales in the United States (Berger 2001)..$^{75}$

The diamond industry is now changing rapidly, and many innovative efforts scheme to skip over the proverbial middleman, which has been the very source of the ultra-Orthodox Jews' comparative advantage. The ultimate success of new cutting ventures and marketing strategies-and with them, the future role of the ultra-Orthodox-may be known soon. The next decade could mark an important turning point in the 1,000-year history of Jews in the diamond trade.

\section{REFERENCES}

Abicht, Ludo. 2002. Antwerp: The Jerusalem of the West. In Dutch Jewry: Its History and Secular Culture (1500-2000), eds. Jonathan Israel and Reinier Salverda, 289300. Leiden: Brill Academic Publishers.

Abrahams, Israel. 1932. Jewish Life in the Middle Ages. London: E. Goldston, Ltd.

Ardener, Shirley. 1964. The Comparative Study of Rotating Credit Associations. Journal of the Royal Anthopological Institute of Great Britain and Ireland 94(2):201-29.

Arkin, Marcus. 1975. Aspects of Jewish Economic History. Philadelphia: Jewish Publication Society of America.

Axelrod, Robert. 1984. The Evolution of Cooperation. New York: Basic Books.

Ayal, Eliezer B., and Barry R. Chiswick. 1983. The Economics of the Diaspora Revisited. Economic Development and Cultural Change 31:861-75.

Banerjee, Abhijit V., and Esther Duflo. 2000. Reputation Effects and the Limits of Contracting: A Study of the Indian Software Industry, Quarterly Journal of Economics 115:989-1017.

Baron, Salo, ed. 1975. Economic History of the Jews. New York: Schocken Books.

Barzel, Yoram. 1977. Some Fallacies in the Interpretation of Information Costs. Journal of Law EO Economics 20:291-307.

1982. Measurement Cost and the Organization of Markets. Journal of Law Eु Economics 25:27-48.

Becker, Gary S. 1993. Human Capital (3rd ed.). Chicago: University of Chicago Press.

Belshaw, Cyril S. 1965. Traditional Exchange and Modern Markets. Englewood Cliffs, NJ: Prentice-Hall.

Ben-Porath, Yoram. 1980. The F-Connection: Families, Friends, and Firms and the Organization of Exchange. Population and Development Review 6(1):1-30.

Berger, Sharon. 2001. Diamonds in the Rough. The Jerusalem Post, April 6, 2001, 4B.

Berman, Eli. 2000. Sect, Subsidy, and Sacrifice: An Economist's View of Ultra-Orthodox Jews. Quarterly Journal of Economics 115(3):905-53.

Bernstein, Lisa. 1992. Opting Out of the Legal System: Extralegal Contractual Relations in the Diamond Industry. Journal of Legal Studies 21(1):115-57.

—. 1996. Merchant Law in a Merchant Court: Rethinking the Code's Search for Immanent Business Norms. University of Pennsylvania Law Review 144:1643-96.

75. Internet sales continue to grow, and Internet and other distribution systems continue to take business away from the traditional channels dominated by family merchants (Rozhon 2005). 
Bernstein, Lisa. 2001. Private Commercial Law in the Cotton Industry: Creating Cooperation Through Rules, Norms, and Institutions. Michigan Law Review 99:1724-88.

Botticini, Maristella, and Zvi Eckstein. 2005. Jewish Occupational Selection: Education, Restrictions, or Minorities? Journal of Economic History 65(4):922-48.

Brenner, Reuven, and Nicholas Kiefer. 1981. The Economics of the Diaspora: Discrimination and Occupational Structure. Economic Development and Cultural Change 29(3):517-34.

Brinig, Margaret F. 1990. Rings and Promises. Journal of Law, Economics $\mathcal{E}$ Organization 6(1):203-15.

Broyde, Michael J. 1996. The Pursuit of Justice and Jewish Law. Hoboken, NJ: KTAV Publishing.

- 1998. Forming Religious Communities and Respecting Dissenters' Rights: A Jewish Tradition for a Modern Society. In Human Rights in Judaism: Cultural, Religious and Political Perspectives, eds. Michael Broyde and John Witte Jr., 35-76.

Buchan, David et al. 2000. The Deadly Scramble for Diamonds in Africa. Financial Times, July 10, 2000, 6.

Carmichael, H. Lorne, and W. Bentley MacLeod. 1997. Gift Giving \& the Evolution of Cooperation. International Economic Review 38(3):485-509.

Carr, Jack, and Janet T. Landa. 1983. The Economics of Symbols, Clan Names, and Religion. Journal of Legal Studies 12(1):135-56.

Clay, Karen. 1997. Trade Without Law: Private-Order Institutions in Mexican California. Journal of Law, Economics $\mathcal{E}$ Organization 13(1):202-31.

Clerizo, Michael. 2004. The Stone's Happy. I Am Happy Too. Financial Times, January 24, 2004, 15.

Coleman, James. 1990. The Foundations of Social Theory. Boston: Harvard University Press.

Cornes, Richard, and Todd Sandler. 1986. The Theory of Externalities, Public Goods, and Club Goods. Boston: Cambridge University Press.

Dasgupta, Partha. 1988. Trust as a Commodity. In Trust: Making and Breaking Cooperative Relations, ed. Diego Gambetta, 49-72. Department of Sociology: University of Oxford.

Dewey, Alice G. 1962. Peasant Marketing in Java. New York: The Free Press of Glenco.

Dore, Ronald. 1983. Goodwill and the Spirit of Market Capitalism. British Journal of Sociology 34:459-82. 1989. Taking Japan Seriously. Palo Alto, CA: Stanford University Press.

Dotson, Floyd, and Lillian O. Dotson. 1968. The Indian Minority of Zambia, Rhodesia, and Malawi. New Haven, CT: Yale University Press.

Dunn, John. 1988. Trust and Political Agency. In Trust: Making and Breaking Cooperative Relations, ed. Diego Gambetta, 73-93. Department of Sociology: University of Oxford.

Ellickson, Robert C. 1989. A Hypothesis of Wealth-Maximizing Norms: Evidence from the Whaling Industry. Journal of Law, Economics Eु Organization 5(1):83-97. 1991. Order Without Law. Boston: Harvard University Press.

Emery, R. W. 1959. The Jews of Perpignan in the Thirteenth Century: An Economic Study Based on Notarial Records. New York: Columbia University Press.

Fafchamps, Marcel. 1996. The Enforcement of Commercial Contracts in Ghana. World Development 24(3):427-48.

Federman, David. 1985. Diamonds and the Holocaust. Modern Jeweler, May 1985.

Fehr, Ernst, and Armin Falk. 2001. Psychological Foundations of Incentives. University of Zurich Institute for Empirical Research in Economics, Working Paper \#95 (2001).

Fehr, Ernst, and Klaus Schmidt. 1999. A Theory of Fairness, Competition, and Cooperation. Quarterly Journal of Economics 114:817-68.

Feifer, Jason. 2004. Diamonds Shine On. Telegram Eु Gazette, April 1, 2004.

Fukuyama, Francis. 1995. Trust: The Social Virtues and the Creation of Prosperity. New York: Free Press. 


\section{LAW \& SOCIAL INQUIRY}

Fullerton, Elizabeth. 2005. Antwerp Battles to Stay World Diamond Capital. Reuters, July 14, 2005.

Gambetta, Diego. 1988. Forward. In Trust: Making and Breaking Cooperative Relations, ed. Diego Gambetta. Cambridge, MA: Basil Blackwell.

Geertz, Clifford. 1962. The Rotating Credit Association: A 'Middle Rung' in Development. Economic Development and Cultural Change 10(3):249-54.

Gerschenkron, Alexander. 1962. Economic Backwardness in Historical Perspective. In Economic Backwardness in Historical Perspective, ed. Alexander Gerschenkron. Cambridge, MA: Harvard University Press.

Granovetter, Mark. 1985. Economic Action and Social Structure: The Problem of Embeddedness. American Journal of Sociology 91:481-510.

Grayzel, Solomon. 1968. A History of the Jews. New York: Jewish Publication Society.

Greif, Avner. 1989. Reputation and Coalitions in Medieval Trade: Evidence on the Maghribi Traders. Journal of Economic History 49(4):857-82.

- 1993. Contract Enforceability and Economic Institutions in Early Trade: The Maghribi Traders' Coalition. American Economic Review 83(3):525-48.

—. 2004. Institutions and Impersonal Exchange: The European Experience. Stanford Department of Economics Working Paper No. 04-009, available at http:// stanford.edu/faculty/workp/swp04009.pdf.

Gutwirth, Jacques. 1968. Antwerp Jewry Today. Jewish Journal of Sociology 10:121-37.

Hazarika, Sanjoy. 1985. India's Flourishing Couriers. New York Times, September 23, 1985, sec. D10.

Hardin, Russell. 2002. Trust and Trustworthiness. New York: Russell Sage Foundation.

Heilman, Samuel. 1992. Defenders of the Faith-inside ultra-Orthodox Jewry. New York: Schocken Books.

Iannaccone, Laurence R. 1992. Sacrifice and Stigma: Reducing Free-Riding in Cults, Communes, and Other Collectives. Journal of Political Economy 100(2):271-91.

Jackson, Bernard S. 2001. Agunah and the Problem of Authority. Lecture delivered on March 13, 2001 under the auspices of the Institute of Advanced Legal Studies, available at http://mucjs.org/2001jlpf.pdf.

Jewish Telegraphic Agency (JTA). 1999. Israeli held on charges of smuggling diamonds. March 3, 1999.

Karp, Jonathan. 1999. Call Them the Icemen: India's Angadias Tote Diamonds in the Rough. Wall Street Journal, March 9, 1999, sec. A1.

Katz, Samuel M. 2001. Israel Has Long Been Known for Its Wholesome Carmel Oranges and Leather Sandals. Today, Israelis Have a Virtual Monopoly on the Global Trade of Ecstasy. Moment. August 2001.

Kenney, Roy W., and Benjamin Klein. 1983. The Economics of Block Booking. Journal of Law EF Economics 26(3):497-540.

Kreps, David. 1990. Corporate Culture and Economic Theory. In Perspectives on Positive Political Economy, eds. J. Alt \& K. Shepsle, 90-143. Cambridge: Cambridge University Press.

Kripalani, Manjeet. 2000. Polishing India's Diamond Business. Business Week, 11 September 2000, p. 126, E8.

Krueger, Anne. 1963. The Economics of Discrimination. Journal of Political Economy, 71(5):481-86.

Landa, Janet T. 1981. A Theory of the Ethnically Homogenous Middleman Group: An Institutional Alternative to Contract Law. Journal of Legal Studies 10(2):349-62. 1988. Underground Economies: Generic or Sui Generis? In Beyond the Informal Sector including the Excluded in Developing Economies, ed. Jerry Jenkins. San Fransciso: ICS Press. 1999. Trust, Ethnicity, and Identity. Ann Arbor: University of Michigan Press. 
Lueck, Thomas J. 1997. Diamond District Tries to Dispel Its Private Bazaar Image. New York Times, December 12, 1997, sec.B1.

Lubin, Albert J. 1982. Diamond Dealers Club: A Fifty-Year History. New York: The Club. Macaulay, Stewart. 1963. Non-Contractual Relations in Business: A Preliminary Study. American Sociological Review 28:55-67.

McMillan, John, and Christopher Woodruff. 1999. Interfirm Relationships and Informal Credit in Vietnam. Quarterly Journal of Economics 114(4):1285-1320.

Milgrom, Paul, Douglass C. North, and Barry R. Weingast. 1990. The Role of Institutions in the Revival of Trade: The Law Merchant, Private Judges, and the Champagne Fairs. Economics and Politics 2(1):1-23.

Montesquieu, M. de Secondat. 2001. The Spirit of Laws. In Montesquieu's Science of Politics, ed. David Carrithers. Oxford, UK: Rowman \& Littlefield.

Muller, Emma. 2001. De Beers Leads the Diamond Trade Downstream. Financial Times, Feburary 1, 2001, 40.

Oppenheimer, Nicky. 1999. Diamonds and Dictators. Washington Post, December 29, 1999, op-ed, 27.

Piramal, Gita. 1990. Sparkle on Indian Diamond Market Dims. Financial Times, June 19, 1990, 8. 1996. Business Maharajas. New Delhi: Viking.

Pogrebin, Robin. 1998. Struggling to Bring Back the Glitter. New York Times, August 23, 1998, sec. 14, 1.

Pollack, Ellen Joan. 2002. The Pretender. New York: Simon \& Schuster.

Porter, Michael. 1985. Competitive Advantage: Creating and Sustaining Superior Performance. New York: Free Press.

Posner, Richard A. 1969. Oligopoly and the Antitrust Laws: A Suggested Approach. Stanford Law Review 21:1562-76.

Putnam, Robert. 1993. Making Democracy Work: Civic Traditions in Modern Italy. Princeton, NJ: Princeton University Press.

Rabin, Matthew. 1993. Incorporating Fairness into Game Theory and Economics. American Economic Review 83(5):1281-1302.

Richman, Barak D. 2004. Firms, Courts, and Reputation Mechanisms: Towards a Positive Theory of Private Ordering. Columbia Law Review 104:2328-67.

Roth, Cecil. 1940. The Jewish Contribution to Civilization. New York and London: Harper \& Bros. Publishers.

- 1961. The Economic History of the Jews. Economic History Review 14(1):131-35. 1961. Essays in Bibliography and Criticism XLV. Economic History Review 57:327-43.

Rozhon, Tracie. 2005. Competition Is Forever. New York Times, February 9, 2005.

Rubin, Sandra. 2001. Diamonds in the Rough. Financial Post, February 3, 2001, sec. D1.

Shainberg, Abe Michael. 1982. Jews and the Diamond Trade. In The Jewish Directory and Almanac, ed. Ivan Tillem, 301-11. New York: Pacific Press.

Silber, Michael K. 1992. The Emergence of ultra-Orthodoxy: The Invention of a Tradition. In The Uses of Tradition: Jewish Continuity in the Modern Era, ed. Jack Wertheimer, 23-84. New York Jersualem: Harvard University Press.

Simons, Marlise. 2006. Twilight in Diamond Land: Antwerp's Loss, India's Gain. New York Times, January 1, 2006.

Smith, Adam. 1976. An Inquiry into the Nature and Causes of the Wealth of Nations, eds. R. H. Campbell, A. S. Skinner, and W. B. Todd. Oxford, UK: Oxford University Press.

Smith, Alex Duval. 1999. The Gem Trail. The Independent, February 13, 1999, 18.

Starr, Roger. 1984. The Real Treasure of 47th Street. New York Times, March 26, 1984, sec. A18.

Time Asia Magazine. 2004. From Rock to Ring. April 19, 2004. 


\section{LAW \& SOCIAL INQUIRY}

Velez-Ibanez, Carlos G. 1983. Bonds of Mutual Trust: The Culutral Systems of Rotating Credit Associations Among Urban Mexicans and Chicanos. New Brunswick, NJ: Rutgers University Press.

Weber, Lauren. 2001. The Diamond Game. New York Times, April 8, 2001, sec. 3, 1.

Weidenbaum, Murray, and Samuel Hughes. 1996. The Bamboo Network: How Expatriate Chinese Entreprenuers Are Creating a New Economic Superpower in Asia. New York: Simon \& Schuster.

Williamson, Oliver. 1985. The Economic Institutions of Capitalism. New York: Free Press. 1991. Economic Institutions: Spontaneous and Intentional Governance. Journal of Law, Economics $\mathcal{E}$ Organization 7:159-87.

—. 1993. Calculativeness, Trust, and Economic Organization. Journal of Law, Economics B Organization 36:453-86.

Zysman, John. 1994. How Institutions Create Historically Rooted Trajectories of Growth. Industrial and Corporate Change 3(1):243-83.

\section{CASES CITED}

Goldfinger v Lisker, 68 N.Y.2d 225 (N.Y. 1986).

Rabinowitz v. Olewski, 473 N.Y.S.2d 232 (N.Y. App. Div. 1984).

Wisconsin Knife Works v. National Metal Crafters, 781 F.2d 1280 (7th Cir. 1986). 